University of Nebraska - Lincoln

DigitalCommons@University of Nebraska - Lincoln

March 1992

\title{
Overlap of Organizations: Corporate Transorganization and Veblen's Thesis on Higher Education
}

\author{
F. Gregory Hayden \\ University of Nebraska - Lincoln, ghayden1@unl.edu
}

Follow this and additional works at: https://digitalcommons.unl.edu/cbafacpub

Part of the Business Commons

Hayden, F. Gregory, "Overlap of Organizations: Corporate Transorganization and Veblen's Thesis on Higher Education" (1992). College of Business Faculty Publications. 46.

https://digitalcommons.unl.edu/cbafacpub/46

This Article is brought to you for free and open access by the Business, College of at DigitalCommons@University of Nebraska - Lincoln. It has been accepted for inclusion in College of Business Faculty Publications by an authorized administrator of DigitalCommons@University of Nebraska - Lincoln. 
JOURNAL OF ECONOMIC ISSUES

Vol. XXVI No. 1 Marsb 1992

\title{
Overlap of Organizations: \\ Corporate Transorganization and Veblen's Thesis on Higher Education
}

\author{
F. Gregory Hayden \\ and \\ Kurt Stephenson
}

This article is built upon the legacy from three of Thorstein Veblen's theories. The first may be best summarized by Martin Gellen who wrote:

Veblen was the first economist to recognize that management was an important factor of production in modern business enterprise, and nowhere was this more evident than in the rise of the large corporation.... These new enterprises took over from the market the coordination and integration of the flow of goods and services all the way from the production of the raw materials through the several processes of production to the sale of the ultimate consumer.... Veblen perceived correctly that administered production by means of large corporations would eventually spread throughout most of the economy [Gellen 1984, pp. 82-83].

The second is his observation that the economy should be described

The authors are Professor of Economics and economics graduate student respectively at the University of Nebraska-Lincoln. The authors benefited greatly from the extensive critique that Paul Dale Bush made of an earlier draft, and wish to thank him for his effort and suggestions. We also wish to thank Brian Svoboda for his data collection and computer programming, and Larry Vogler for further computer programming. Finally, we thank Timothy Kannmacher for his research on Thorstein Veblen's thesis on higher learning. 
as a network of sequential events and decisions [Veblen 1898]. Veblen's theory on the decisionmaking apparatus of higher education [Veblen 1957], which will be summarized below, is the third theoretical leg of the surveyor's tripod used for the observations in this article.

The purpose of this research is to accomplish the following: first, to extend the conceptual framework of transorganizational research through the Social Fabric Matrix and Digraph [Hayden 1982a and $1982 \mathrm{~b}$. The literature on transorganizational research is found under topics such as interorganizational organization in sociology, directorship interlocks in economics, and organizational structure in management studies. Second, to apply the extended framework to corporate translocks in the state of Nebraska. Consistent with the work of Bert M. Evans [Evans 1980] and John R. Munkirs [Munkirs 1985], this section will articulate the integration of Nebraska's centrally coordinated planning system that results from the integration of private corporations. The articulation will include the determination of what Evans called the "dominant core" corporations-what Munkirs designated the "central planning core" (CPC). Third, the Nebraska CPC (NCPC) data base is used in conjunction with Veblen's thesis on decisionmaking in higher education, to analyze the relationship between the NCPC and the University of Nebraska.

\section{Overlap Among Organizations}

As the social sciences have attempted to move beyond self-actional and interactional modeling to transactional modeling, an important concern has been how to model the overlap or relationships among organizations. Although the prefix "inter" is a misnomer in a transactional world, this literature is sometimes referred to as dealing with "interorganizational organizations." Those employing self-action models assumed that the behavior of entities or agents is determined by inner drives, or motives, or rational utility calculations. With interactional (inter means between) models, it was assumed that the actions and reactions among entities determine reality. Most interaction models followed the equilibrium models of Newtonian physics, where entities are balanced against each other, the antiquated model of the interaction and balance between supply and demand is an example. Transactional (trans means across) models are based on the more recent knowledge that proscriptive and prescriptive criteria, customs, and control organizations are across and above the entities and guide the behavior of those entities in non-isomorphic fields. In a transac- 
tional, or holistic setting, the social organizations as well as their integration linkages (connectives, locks) are created and maintained by the actions, rules, and customs that are across the particular entities of the system. Reality is not disintegrated; it is scientists who reduce the world to disintegrated units with self-actional and interactional models. More recently, the scientific job has been discovering how to model transactional systems and holistic networks.

The psychologist, Arthur Bentley, and the economist, John R. Commons, were two early scholars who developed applied transactional analysis. John $\mathbf{R}$. Commons defined transactions as the smallest economic unit that can be regularly observed for scientific purposes. Thus, when he observed the transaction of buying and selling, it was not to give extraordinary meaning to the price artifact, but rather to take account of judicial, social, psychological, political, economic, energy, and natural components both across and determining the transaction of buying and selling [Commons 1968].

Sociologists Huseyin Leblebici and Gerald Salancik, in their analysis of the Chicago Board of Trade, began with Commons's concepts. Their study reports how stability of transactions is achieved through transorganizational working rules. They found that "from the view of a theory of organization, this implies that the exchange transactions observed in any interorganizational field are not solely under the control and discretion of exchange partners themselves, but are the product of collective rule making which produces order out of conflict and mutuality" [Leblebici and Salancik 1982, p. 241]. Commons found that for transactions to proceed, there must be a collective guarantor to the transaction. "Because of this need for the guarantor, a transaction is not a result of the exchange between two parties, ... but rather the result of the collective powers" [Leblebici and Salancik 1982, p. 229].

The modeling of the transactional relationships among organizations can by guided by a number of different methodological approaches. The institutionalist approach is one of overlap of the process and decisionmaking of related organizations. The environment around any organization is itself made up of other organizations. Thus, the overlap itself is an institutional entity and of scientific interest to the institutional researcher [See: Bush 1983 and 1987]. The organizations are not separate; they are provided with functions, criteria, and decisionmakers that integrate the overlapping organizations. The structure and process of each organization is part of other organizations. In this article, the institutional and transactional approach will be used.

Consistent with such utilization, terms to designate linkages, locks, 
deliveries, and connectives will, when prefixed, be prefixed with "trans" rather than "inter" in order to be consistent with transactional analysis. The etymology and specification of the prefix "inter" is inconsistent with the manner and means through which relations among organizations are established and maintained. The distinction is important with regard to policy concerns. If relationships among organizations were really limited and determined by those organizations, they would be immune to public policy. If it is, however, understood and designated that the functioning of relationships depends on the transactional beliefs, criteria, customs, policies, laws, and rules that exist across and outside the particular organizational transaction, then it is possible to redesign those transactions through public policy. As John Dewey and Arthur Bentley stated, "naming does things. It states. To state, it must both conjoin and disjoin, identify as distinct and identify as connected" [Dewey and Bentley 1949, p. 133]. If the naming is inconsistent with the identification of what is known, the misdesignation will encourage the development of policy inconsistent with scientific findings.

\section{Relevant Corporate Transorganizational Literature}

The "interorganizational organization" literature in sociology dates back to at least the 1800 s, and includes studies on families, corporations, markets, government agencies, military confederations, classes and so forth. An important part of that literature deals with the overlap of corporations, especially the exchange of directors among corporate boards. What has been missing in such studies, according to Charles J. Fombrun, has been an integrated transactional, or holistic, approach for understanding and modeling the full sociostructure "as firms struggle to manage their common fate" [Fombrun 1986, p. 411].

In his book, The Transformation of American Capitalism, John Munkirs argues, consistent with Evans, that most of the production and distribution decisions in the American economy are not made by the invisible hand of the market, but by a small number of closely linked corporations [Munkirs 1985]. Munkirs traces the evolution of the American economy from the birth of industrial trusts after the Civil War to the present day economy, dominated by "centralized private sector planning" (CPSP). At the center of the CPSP process is a small number of large banks and insurance corporations, which Munkirs labels the "central planning core" (CPC). The CPC possesses an impressive array of both formal and informal planning instruments with 
which to coordinate and direct economic activity. Formal planning instruments available to the CPC include shared stock and debt ownership and overlapping boards of directors. Informal planning instruments, which serve as a network of informational conduits among CPC corporations, include legal and financial services such as shared trustees, registrars, and transfer agents. The CPC delivers information and direction through these collective planning instruments to corporations in vital industrial, transportation, and retail sectors of the economy. What emerges from this private centrally planned process is a technologically, financially, and administratively overlapping group of large corporations.

Munkirs developed and organized a substantial data base for his book. His empirical work leads us to a new theory of the firm. The locus of a corporation's decisionmaking in the modern economy is not based on marginal cost and revenue considerations of an independent competitive firm as explained by Alfred Marshall; it is not based on the mutual dependence recognized considerations of an oligopoly firm as explained by Edward Chamberlin; and it is not the result of the team of technocrats in the large corporation as emphasized by John Galbraith. According to Munkirs, the locus of decisionmaking is the recognized planning arrangements undertaken and enforced jointly by overlapping governing boards and other planning instruments of global corporations.

Munkirs demonstrates empirically how in one industry after another governing boards are connected to the CPC and to other governing boards through different kinds of overlaps. Through his elaboration of a central planning tableau, he shows how the CPC has placed itself in a position to plan for more than 100 of the largest U.S. corporations. The tableau demonstrates:

- how firms in a given industry ... are technologically, financially, and administratively interdependent;

- how each of several industries ... are technologically, financially, and administratively interdependent; and

- how over the years, a series of planning instruments have evolved that both allow and indeed, to some extent, necessitate regional, national, and international centralized private sector planning [Munkirs 1985 , p. 5].

Munkirs's work leaves us with a general theory regarding the importance of centralized patterns in organizational overlap, and with methods to meet Fombrun's call for modeling the complex constructs of full 
sociostructures. Our goal is to refine the concept of organizational overlap, and to explain methods which can be used to identify and derive centralized patterns of overlap.

\section{Overlap and Reachability Concepts}

Conceptually, the concern is with the overlapping sets that define the network and delivery process. This can be explained with the use of the simple digraph (directed graph) in Figure 1. Assume that E,F,G,H, and I are five organizations-five different corporations in this case. Corporations can make various kinds of deliveries to each other. In this case we will be concerned with the delivery of directors. The deliveries among the organizations, for example directors $D_{1}$ through $D_{\text {, in Figure }}$ 1, are an important part of their transorganizational relationships. The importance, or central position, of any corporation would depend on the number of different kinds of transorganizational sets in which the corporation is involved, and on the number of deliveries within each set. If two corporations each send one director to the other's board, the degree of overlap would be less than if the same corporations shared four directors.

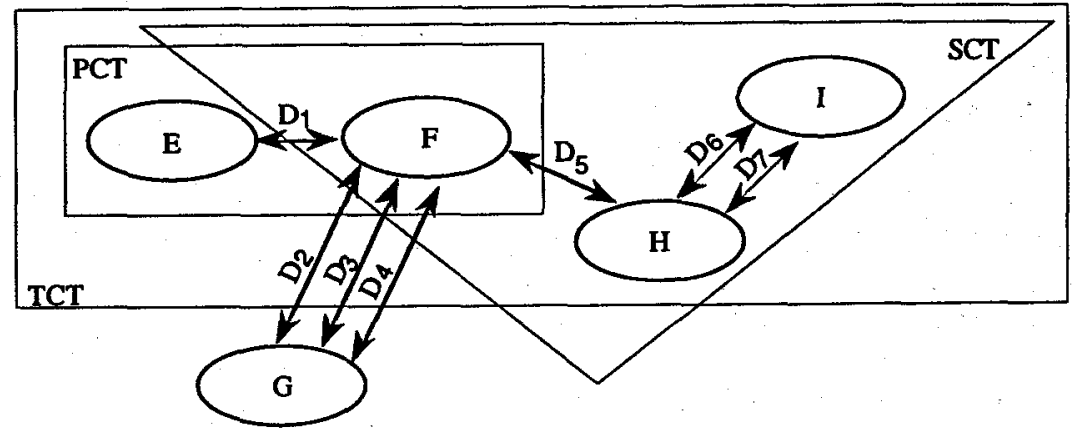

Figure 1. Organization Overlap and Reachability Digraph

We are specifying three different kinds of organizational overlap sets. They are primary, secondary, and tertiary sets, which are demonstrated in Figure 1 with the use of dotted lines to outline the different sets.

Primary Overlap: A primary corporate translock (PCT) is outlined in Figure 1 with the rectangle around $E$ and $F$. (Appendix A contains a glossary of acronyms and symbols for the reader's convenience.) As in- 
dicated, director $D_{1}$, serves on the boards of corporations $E$ and $F$. Corporation $\mathrm{E}$ is involved in one $\mathrm{PCT}$ with $\mathrm{F}$ and has one primary director translock (PDT). The PDT indicates the delivery level (number delivered). Although not outlined by a dotted line in Figure 1, other PCT sets include those between $G$ and $F, F$ and $H$, and $H$ and $I$. Corporation G, for example, has one PCT and three PDTs with corporation F. With a primary overlap, the directors on the two governing boards meet together at each other's board meetings to plan together for the two corporations involved.

Secondary Overlap: A secondary corporate translock (SCT) is outlined in Figure 1 by a set (enclosed by a triangle) which includes corporations $F, H$, and I. Corporation I has a SCT with corporation F through corporation $\mathrm{H}$. This example of a SCT has three secondary director translocks (SDT's), which are $\mathrm{D}_{,}, \mathrm{D}_{6}$, and $\mathrm{D}_{r}$ Other SCT sets in Figure 1 incluile $E$ with $G$ and $G$ with $H$. With a secondary overlap, the directors on the two governing boards are still meeting together face-to-face in planning sessions on a third governing board, which has an overlapping interest in the two SCT corporations. There are direct planning relationships between the two companies, and the directors involved have direct face-to-face reachability with regard to decisions in a deliberative setting.

Tertiary Overlap: A tertiary corporate translock (TCT) is outlined in Figure 1 by a dotted line set that includes corporations E,F,H, and I. Corporation $E$ has a TCT with corporation I through corporation $F$ and H. This example of a TCT has four tertiary director translocks (TDTs). They are $D_{b}, D_{5} D_{6}$, and $D_{7}$. Unlike primary and secondary corporate overlaps, there are not necessarily direct face-to-face relationships at a governing board meeting between the directors from $E$ and $I$. To use the example in Figure 1 , after $D_{1}$ and $D_{5}$ meet at corporation $F$, deliberative decisions and plans, if they are to include corporation I, must take place at the board meeting of corporation $\mathrm{H}$. $\mathrm{E}$ has reachability to I, but it can be once removed from direct face-to-face planning deliberations, as indicated in Figure 1. Another TCT in Figure 1 is $G$ with I though $F$ and $H$, with six TDTs. The TDTs are $D_{1}, D_{5}, D_{6}$ and $D_{r}$

Figure 1 is, of course, too limited to portray all the various sets of corporations in a real world context. We can observe from Figure 1, however, that corporation $F$ is a central organization in the process network. It is involved in more organizational overlap sets, and has more reachability to other corporations, and a greater level of deliveries, in terms of directors, than any other corporation. It lies in the intersection of all three sets. 


\section{Extension with the Social Matrix and Digraph}

The Social Fabric Matrix (SFM) can be used to extend the organization overlap concepts and to apply the concepts to the complex and redundant overlaps of the real world. To explain this application of the SFM, corporations $\mathrm{A}, \mathrm{B}, \mathrm{C}, \mathrm{J}$, and $\mathrm{K}$ are arrayed along both sides of the matrix in Figure 2, and the delivery of directors from one corporation to another corporation is indicated in the cells. For example, corporation $A$ delivers its board member $X$ to the board of corporation $B$, and member $Z$ to corporation J. As another example, $C$ delivers $Y$ to $B, Z$ to $J$, and two members, $N$ and $M$ are sent to $K$. The rows and columns can be aggregated as in Figure 2, and thus the various overlaps defined above are specified in the matrix as follows:

\begin{tabular}{|c|c|c|c|c|c|c|c|c|}
\hline \multirow{2}{*}{\multicolumn{2}{|c|}{\begin{tabular}{|l}
\multicolumn{1}{c}{ Receiving } \\
Corporations \\
Delivering \\
Corporations
\end{tabular}}} & \multirow{2}{*}{$\frac{(1)}{A}$} & \multirow{2}{*}{$\frac{(2)}{B}$} & \multirow{2}{*}{$\frac{(3)}{c}$} & \multirow{2}{*}{$\frac{(4)}{J}$} & \multirow{2}{*}{$\frac{(5)}{K}$} & \multirow{2}{*}{$\begin{array}{c}\text { (6) } \\
\begin{array}{c}\text { Total } \\
\text { Entries }\end{array} \\
\end{array}$} & \multirow{2}{*}{$\begin{array}{l}\text { (7) } \\
\text { Row } \\
\text { Total }\end{array}$} \\
\hline & & & & & & & & \\
\hline (1) & $\rightarrow$ & $\rightarrow \rightarrow$ & $1 x$ & & $\mathbf{Z}$ & & 2 & 2 \\
\hline (2) & $\overline{\mathbf{B}}$ & $\mathrm{x}$ & i: & $\mathbf{Y}$ & $\mathbf{N}$ & & 3 & 3 \\
\hline (3) & C & ++ & $A \rightarrow Y_{+}$ & $\rightarrow+\rightarrow$ & +74 & $\rightarrow N_{2} M_{4}$ & 3 & 4 \\
\hline (4) & $\mathbf{J}$ & $\mathbf{Z}$ & N & $\mathbf{z}$ & & $I$ & 4 & 4 \\
\hline (5) & $\mathrm{K}$ & & 1 & $\mathbf{N}, \mathbf{M}$ & I & & 2 & 3 \\
\hline (6) & Total Entries & 2 & 3 & 3 & 4 & 3 & & \\
\hline (7) & Column Totals & 2 & 3 & 4 & 4 & 3 & & \\
\hline
\end{tabular}

Figure 2. Social Fabric Matrix of Corporate Direct Deliveries.

PCT: The total PCT's a corporation has with other corporations is the total number of cells with entries in the corporation's row in the SFM. For example, the row total for cell entries for corporation $C$ is 3.

PDT: The total PDTs involved in a corporations PCTs is the total number of directors in a corporations row. For example, the row total for directors for corporation $C$ is 4 .

SCT: The total SCTs a corporation has with other corporations is the total number of cells with entries, less 1 , in the column, for columns with a corporation's director delivery to a PCT. For example, the total SCTs for corporation A can be found by the aggregation of the cell entries of columns 2 and 4 , less 1 for each column. Or, corporation $A$ is involved in 5 SCTs $[(3-1)+(4-1)=5]$. To find the SCTs for A, read 
across the row from left to right (as indicated with the directed dashed line). In column 2, director $X$ from $A$ is serving on the board of $B$ (a $P C T)$. If we read down, it will be discovered that corporations $C$ and $J$ also deliver $\mathrm{Y}$ and $\mathrm{N}$ respectively to the board of $\mathrm{B}$. Thus, $\mathrm{A}$ has a SCT with $C$ and another with $J$ through B. Because B is the direct PCT through which the SCTs with $C$ and $J$ are accomplished, it is not counted in the total. A similar SCT case exists in column 4.

SDT: The total SDTs participating in a corporation's STCs is the total number of directors in the column that contains a corporation's delivery of directors to a PCT. For example, the total SDT for corporation $A$ can be found by the aggregation of the cell entries of columns 2 and 4 , for a total of 7. To find the SDT total for A, read across the row from left to right. In column 2, director X serves on the board of B. All of the directors in column 2 are members of the SDT. A similar SDT case exists in column 4 , in which there are four SDTs.

TCT: The total TCTs to which a corporation belongs is the total number of cells with entries, less 1 , for rows in which there is a corporation with which the original corporation has an SCT. For example, the total TCTs for corporation A can be found by the aggregation of the cell entries, less 1 , for each row, for rows 3 and 4. Or, stated differently, corporation A participated in 5 TCT's $[(3-1)+(4-1)=5]$ through corporation $B$. To find a TCT for A, read across row 1 (still following the directed dashed line) from left to right to a PTC (column 2), go down that column to a SCT, and then aggregate all the cell entries in that row (row 3) minus 1. The 1 is subtracted in that row for the SCT through which the TCT is formed. A similar TCT case exists for row 4. This calculation would need to be repeated (not indicated by dashed lines in Figure 2) for each SCT through corporation J in column 4 to obtain the total number of TCTs for corporation A, or 5 TCTs [(3-1)+(3-1)+ $(2-1)=5]$. Thus, the total TCTs for corporation A is 10, [5+5].

TDT: The total TDTs are the total number of directors in the TCT rows plus the number of directors in the PCT cell from which each TCT originates. For example, the total for corporation $A$ is 23 . To find the TCT total for A, read across the row from left to right. There is 1 director in PCT cell $(1,2)$. Reading down from cell $(1,2)$, row 3 has 4 directors plus the 1 director in cell $(1,2)$. A similar process is followed for row 4. Reading down from cell $(1,4)$, row 2 has 3 directors plus the 1 director in cell $(1,4)$ from which the TCT in row 2 originates. A similar process is followed for rows 3 and 5 . Thus $[(4+1)+(4+1)+(3+1)+(4+1)+$ $(3+1)]=23$.

The matrix in Figure 2 is laid out in digraph format in Figure 3, 
which clarifies reachability and redundancy. By observing Figure 3, it is more obvious that corporation $A$ reached $J$ through numerous channels-with a direct PCT, with a SCT through B, and with a TCT through $B$ and $C$. These redundant linkages enhance the opportunity for the decisions and plans to be made conjointly and implemented effectively. Numerous corporations govern in a manner that relies on corporation $J$ effectively maintaining the plan coordinated with corporation $A$, and the directors from those corporations who sit on the governing board of J emphasize that reliance. These are redundant reinforcement channels. Equally important, all those corporations reach A. Stated differently, A reaches itself indirectly through these linkages. At first blush this statement may sound irrelevant. Yet, upon reflection, it means that the directors delivered to A's board from other corporations can remind A of A's original decisions and their reliance on the original decisions, and thereby reinforce the plan that leads to continuity of the economic process. This planning transmission cycle is consistent with the institutional theory of cumulative circular causation.

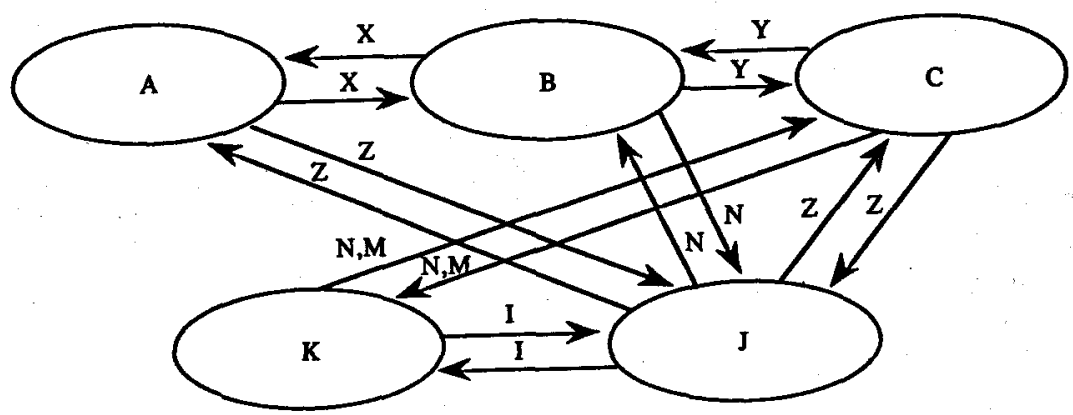

Figure 3. Social Fabric Digraph of Corporate Director Deliveries

\section{Nebraska Corporations}

To articulate the network process of organization overlap among private corporations in Nebraska, we began by collecting for each corporation the names of directors and officers, the value of assets and sales, and the names of the law firms and accounting firms used by each corporation.' After an arduous and lengthy search, such data were collected on 348 Nebraska corporations. 


\section{Pattern of Nebraska Corporate Overlap}

Early in the data collection process, it became apparent from casual observation that there is considerable overlap among the governing boards of Nebraska corporations. Computer assistance made it possible to select only corporations having at least one PCT. Next, to discover the pattern of the overlapping governing boards, the corporations with at least one PCT were entered into a Social Fabric Matrix (as explained above). The list included 100 corporations, thus requiring a matrix of 100 rows and 100 columns. The number of directors from each corporation that serves on another board were entered into the relevant matrix cells, and the PCTs, PDTs, SCTs, SDTs, TCTs, and TDTs were aggregated in the type of matrix explained above and illustrated in Figure 2.2 The results of the aggregation, for those corporations with four or more PCTs, are rank ordered in columns 1 and 2 of Table 1, along with the number of PDTs in column 3. There were 30 corporations with four or more PCTs. FirsTier Financial, the top ranked in direct board connections, had 30 PCTs and 42 PDTs. This means FirsTier had at least one of its directors serving on 30 other Nebraska corporation boards; and on the boards of other corporations, FirsTier held 42 board positions.

In determining director deliveries among boards, board members of subsidiary corporations were included as members of the parent corporation's board. This was one in order to not multiply the apparent number of translocks of particular boards and members. Board members from the parent company are often on the subsidiary board. We did not consider that arrangement as constituting a separate corporate overlap because these members all belong to the same corporation. Had such internal deliveries of board members been counted, the totals in Table 1 would have multiplied considerably.

The ranking by the number of SCTs is given in columns 4 and 5 of Table 1. The corporations with 30 or more SCTs are listed. Column 6 contains their corresponding number of SDTs. Of interest are the corporations that did not make the PCT and PDT list, which are included in the SCT and SDT list. They are Farmers Mutual Insurance, Woodmen Accident and Life, Mutual of Omaha Insurance Co., IBP, Mall Corp., and the Nebraska Farmer (all indicated with an asterisk in Table 1, column 4). These are all corporations which were connected with a PCT to FirsTier. Any corporation with a PCT to FirsTier would automatically be involved with at least 29 SCTs. This allows us to see that a corporation can be well connected and prominent in the system without a large number of PCTs if its PCTs are with other central corporations. As an example, Mutual of Omaha has only three PCTs, but one 
is with FirsTier. The reverse of that situation can be seen with First National of Nebraska, parent of First National-Omaha. First National of Nebraska appears in column 1, but not in columns 4 and 7. It does not have a PCT with FirsTier Financial or with other central corporations; thus, it does not generate enough SCTs to qualify for the list in column 4.

The ranking by the number of TCTs appears in columns 7 and 8 of Table 1. Those corporations with 170 or more TCTs are listed. Column 9 contains their corresponding number of TDTs. As with the SCT ranking, there are corporations in the top 26 with respect to the number of TCTs that are not listed in columns 1 and 4 (as indicated by an asterisk). Of greater interest, the SFM allows us to discover the large number of other corporations that any corporation can reach on a tertiary basis. For example, FirsTier with 30 PCTs, is involved in 447 tertiary board overlaps and has 886 TDTs.

At this point in our analysis, it is apparent that Nebraska has a centralized private sector planning (CPSP) system similar to that found by Munkirs for the national economy [Munkirs 1985]. Some differences are also apparent. For those familiar with Munkirs's findings, one apparent difference is that the Nebraska system is more centralized than the national system in the distribution of direct board of directors translocks and in the board members involved in the translocks. Nebraska's PCTs and PDTs are both less equally distributed than at the national level. However, the centricity of the system and reachability within the system, rather than differences with the national system, are the interests in this article.

\section{Nebraska Central Planning Core}

The criterion used to determine the corporations that make up the Nebraska Central Planning Core (NCPC) is the degree of reachability of a corporation to the dominant corporations at the center of the core decision network. From Table 1, it is clear that FirsTier Financial, Lincoln Telecommunications, First Commerce Bancshares, and Ameritas Life Insurance are the top four corporations with the most connections in PCT, SCT, and TCT categories. In addition, all four have a PCT with the other three. Because these four corporations are the most central, the other corporations in Table 1 are ranked with respect to their reachability to these central corporations. Some corporations listed in Table 1 were deleted from consideration as a NCPC corporation because of their relatively small size. ${ }^{3}$ In addition, some corporations, such as IBP and Pegler-Sysco, were deleted from consideration 
because it was the authors' assessment that the major decisions for those corporations were made outside Nebraska. IBP is a subsidiary of Occidental Petroleum and the national corporate headquarters of Pegler-Sysco is in Houston, Texas.

The final list of corporations comprising the NCPC are in Table 2 along with the total number of various types of translock sets by which each corporation reached the four leaders. For example, in the case of Valmont, FirsTier is reached through a PCT, 5 SCTs and 17 TCTs. After determining the connections to the four central corporations, the lock sets are weighted by assigning each PCT a weight of 5, each SCT the weight of 3 , and each TCT the weight of $1 .^{4}$ The total, determined by multiplying the number of PCTs, SCTs, and TCTs by their respective weights, is found in the final column of Table 2. Using this manner of determination, it was found, for example, that Crete Carrier (with a total of 112) has over two and one-half times the reachability to the central corporations as Guarantee Mutual Life (with a total of 42). The NCPC consists of four banks (FirsTier, First Commerce Bancshares, Norwest Nebraska, and Union Bank and Trust); five insurance companies (Guarantee Mutual Life, Woodmen Accident and Life, Farmers Mutual, Security Mutual Life, and Ameritas Life); one investment holding corporation (Berkshire Hathaway), and five production corporations (Crete Carrier, ConAgra, Peter Kiewit, Lincoln Telecommunications, and Valmont Industries).

Directorship deliveries among the NCPC corporations are indicated in the NCPC Social Fabric Matrix contained in Figure 4, and in the NCPC Social Fabric Digraph contained in Figure 5. The deliveries are found by reading the SFM across from left to right. For example, as indicated in row 1, FirsTier delivers 4 directors (4 PDT's) to Woodmen, 3 to ConAgra, 3 to Valmont, and so forth. The total PCTs for each corporation within the core is found in column 16 and their total PDTs within the core are found in column 17. By adding each column, less one, where FirsTier has a PCT, the total SDTs in the core can be determined for FirsTier. For example, in Column 14, the director delivered from FirsTier to Lincoln Telecommunications (cell 1,14) meets with directors who also serve as directors of First Commerce Bancshares, Ameritas Life, Woodmen, and so forth, because directors from those corporations also serve on Lincoln Telecommunication's board. To find the TDTs, as explained earlier in Figure 2, one would read left and right from each SDT. For example, FirsTier's SDT in cell $(3,14)$ also allows FirsTier to reach Norwest Nebraska in cell $(3,2)$ to provide information and influence on a tertiary basis. 


\begin{tabular}{|c|c|c|c|c|c|c|c|c|c|c|c|c|c|c|c|c|c|c|}
\hline 3 & 5 & 5 & $\widehat{E}$ & $\widehat{\omega}$ & $\widehat{\mathbb{N}}$ & & $\widehat{\bar{\theta}}$ & & $\circledast$ & 3 & क & 5 & E & ఱ్ర & $\mathbb{Q}$ & $\Xi$ & \multirow{2}{*}{\multicolumn{2}{|c|}{ | }} \\
\hline 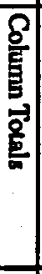 & 䓃 & 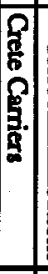 & 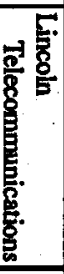 & 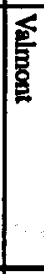 & 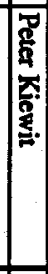 & 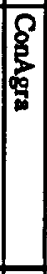 & 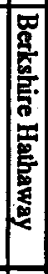 & 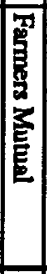 & 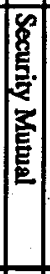 & \begin{tabular}{|l|} 
\\
\\
8 \\
8 \\
8 \\
8 \\
8 \\
8 \\
8 \\
0 \\
5 \\
5 \\
\end{tabular} & 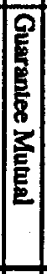 & \begin{tabular}{|l} 
\\
\\
\\
\\
5 \\
\end{tabular} & 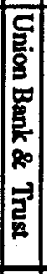 & 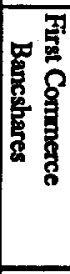 & 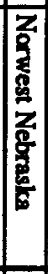 & 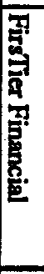 & & \\
\hline ㄴ. & 히 & & $\hat{\boldsymbol{B}}$ & $\boldsymbol{\omega}$ & 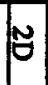 & $\omega$ & $\theta$ & $\hat{a}$ & & 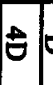 & $\sigma$ & $\underline{\Omega}$ & & $\theta$ & & & \begin{tabular}{|l|} 
FirsTier \\
Financial
\end{tabular} & $E$ \\
\hline$\rightarrow$ & $N$ & & & & & & & & & & $\omega$ & & & $\theta$ & & & $\begin{array}{l}\text { Nonwest } \\
\text { Nebraska }\end{array}$ & $\widehat{\mathbb{N}}$ \\
\hline 히 & $a$ & & $\hat{\theta}$ & $\theta$ & & & & & $\theta$ & & & $\boldsymbol{\theta}$. & & & $\theta$ & $\theta$ & $\begin{array}{l}\text { First Commerce } \\
\text { Bancshares }\end{array}$ & $\omega$ \\
\hline N & - & ș & & & & & & & & & & & & & & & Union Bank & $\Phi$ \\
\hline ㅇ) & $u$ & $\nabla$ & $\theta$ & & & & & $\theta$ & & & & & & $\theta$ & & $\underline{\theta}$ & Ameritas & $\Xi$ \\
\hline$\rightarrow$ & $N$ & & & & & & & & & & & & & & $\ddot{\sigma}$ & $\theta$ & $\begin{array}{l}\text { Guarantee } \\
\text { Mutual }\end{array}$ & $\widehat{a}$ \\
\hline a) & $N$ & & $\vec{\theta}$ & & & & & & & & & & & & & $\theta$ & $\begin{array}{l}\text { Woodmen } \\
\text { Acc. \& Life }\end{array}$ & 3 \\
\hline$u$ & $N$ & & $\theta$ & & & & & & & & & & & $\vec{\theta}$ & & & $\begin{array}{l}\text { Security } \\
\text { Mutual }\end{array}$ & ळ \\
\hline$\rightarrow$ & $\omega$ & & $\boldsymbol{\theta}$ & & & & & & & & & $\theta$ & & & & s & $\begin{array}{l}\text { Farmers } \\
\text { Mutual }\end{array}$ & to \\
\hline$\rightarrow$ & $\rightarrow$ & & & $\theta$ & $\boldsymbol{O}$ & $\theta$ & & & & & & & & & & $\theta$ & $\begin{array}{l}\text { Berkshire } \\
\text { Hathoway }\end{array}$ & s \\
\hline 하 & $\rightarrow$ & & & $\boldsymbol{\omega}$ & $\underline{\omega}$ & & $\nabla$ & & & & & & & & & $\boldsymbol{\sigma}$ & ConAgra & $\mathbf{E}$ \\
\hline$\infty$ & $\Delta$ & & & $\tilde{\nabla}$ & & $\ddot{\sigma}$ & $\theta$ & & & & & & & & & 붕 & $\begin{array}{l}\text { Peter } \\
\text { Kiewit }\end{array}$ & $\mathbb{N}$ \\
\hline $\bar{N}$ & $a$ & & $\theta$ & & $\ddot{\boldsymbol{\theta}}$ & 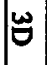 & $\theta$ & & & & & & & $\theta$ & & $\ddot{g}$ & Valmont & $\underline{E}$ \\
\hline$\mp$ & $\infty$ & $\nabla$ & & $\theta$ & & & & $\theta$ & $\theta$ & E & & $\vec{\theta}$ & & $\mathfrak{v}$ & & $\underline{G}$ & $\begin{array}{l}\text { Lincoln Telecom- } \\
\text { munications }\end{array}$ & $\Xi$ \\
\hline$\rightarrow$ & $\boldsymbol{\omega}$ & & $\boldsymbol{\theta}$ & & & & & & & & & & $\tilde{U}$ & & & & Crete Carriers & $\underline{E}$ \\
\hline & & $\omega$ & $\infty$ & $a$ & A & $\infty$ & + & $\omega$ & $N$ t & $N$ & $N$ & $u t$ & - & $a$ & $N$ & $\sigma$ & Total Entries & $\widehat{\Xi}$ \\
\hline & & $\rightarrow$ & $\bar{A}$ & $\bar{N}$ & 6 & $\sigma$ & $\triangle$ & $\rightarrow$ & a & $a$ & $\rightarrow$ & o) & $N$ & $\overline{0}$ & $\rightarrow$ & $\underline{N}$ & Row Totals & 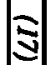 \\
\hline
\end{tabular}




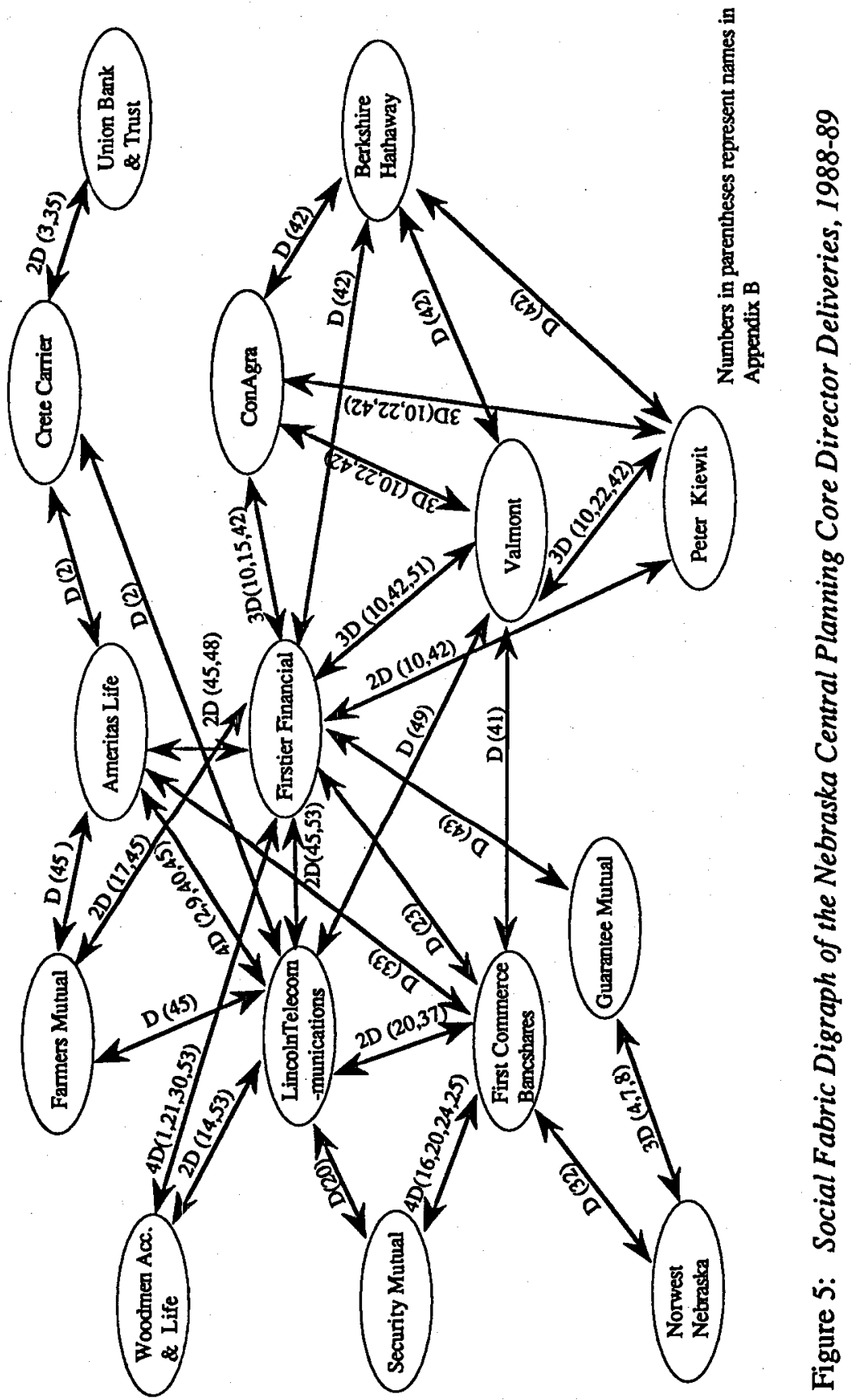


The translock network among these central core corporations is easier to conceptualize by observing Figure 5 . In Figure 5 the nodes are the component corporations and the edges (lines) are the deliveries of directors. Since the director delivery is in both directions, only one line with an arrow on each end is used. For example, if two corporations, such as FirsTier and First Commerce Bancshares, both have a director serve on the other's board, that is indicated with one edge. Numbers are used in Figure 5 to represent the director's names. That number and the name to which it corresponds are found in Appendix B. The names of directors are included in order that readers may correct us if the public documents from which the data base is compiled are inaccurate, and in order to allow others to complete a surname analysis.

These corporations exchange governing board members, plan together on each others' boards, and exchange information through direct and indirect linkages and planning functions. Within the NCPC, 13 of the 15 members deliver a president or CEO to other core corporations. In addition, although the data base is not contained in this article, some keep deposits with each other, serve as each others' agents, and own each others' stock. Because these corporations are highly integrated, the welfare of one affects the welfare of others. Thus, it is a system of mutual advantage recognized arrangements, to use Bert Evans's term, through which they (legally and systematically) plan together. They do not belong to a competitive system of decentralized, independent free enterprise. They belong to a centralized private sector planning system, to use John Munkirs's term, of which they are the central core members. We see that the NCPC is closely integrated in its decisionmaking functions and is an information diffusion system. Through this network, and through their numerous overlaps with other Nebraska corporations (see Table 1), these corporations can diffuse their plans across the corporate board structure of the Nebraska economy.

\section{The Nebraska CPC and the University of Nebraska}

Next we will use Thorstein Veblen's ideas relevant to university administration as a guide to relate the Nebraska CPC to the administration of the University of Nebraska. Veblen's relevant work on the subject is his book, The Higher Learning in America: A Memorandum on the Conduct of Universities by Business Men [Veblen 1957]. The subtitle is the important aspect for our purposes here. (Especially relevant to the Nebraska case is the use of the word "Men.")"

Veblen found the maxims that guided the major universities of his 
day did not lead them to be in the service of science and scholarship, but rather, the maxims that guided their conduct were those found in the marketplace and the world of pecuniary gain. The reason their conduct was so directed was because the universities were dominated by governing boards made up of businessmen and university presidents with powerful positions. Therefore, the "aims and methods of the scholars and schools devoted to the higher learning" [Veblen 1957, p. 3] are found to be influenced by the "habitual pursuit of business in modern times" [Veblen 1957, p. 3].

The university administrative apparatus reflected the secularization of the United States by the substitution of laymen for clergymen on the governing boards. Veblen wrote, "the substitution is a substitution of businessmen and politicians; which amounts to saying that it is a substitution of businessmen. So that the discretionary control in matters of university policy now rests finally in the hands of businessmen" [Veblen 1957, p. 46]. He found that "poor men and men without large experience in business affairs are felt to have no place in these bodies" [Veblen 1957, p. 47]. The effective control of the university, according to Veblen, "is exercised through the board's control of the budget" [Veblen 1957, p. 58], because "the academic staff can do little else than what the specifications of the budget provide for ... " [Veblen 1957, p. 58]. The power of the purse gives the governing boards the power to establish the beliefs and criteria to guide the university, and "the fact is that businessmen hold the plenary direction, and that business principles guide them in their management of the affairs of the higher learning..." [Veblen 1957, p. 57]. The academic administrator is "vested with somewhat autocratic powers" [Veblen 1957, p. 59] by the board and "he is in effect responsible to the governing board alone" [Veblen 1957, p. 59] and therefore the mind set of the board; a mind set which does not habitually look beyond the "interest of commercial gain and the commonplaces of commercial routine and political bravado" [Veblen 1957, p. 174].

Veblen found that business boards, as a rule, "will be careful to give their general manager full discretion, and not to hamper him with too close an accounting of the details of his administration, so long as he shows gratifying results. He must be a strong man; that is to say, a capable man of affairs, tenacious and resourceful in turning the means at hand to account for this purpose, and easily content to let the end justify the means" [Veblen 1957, p. 66]. The fierce campaign of aspirants for executive office in universities tests their qualifications against the standards expected by the board, and tests their strength under pres- 


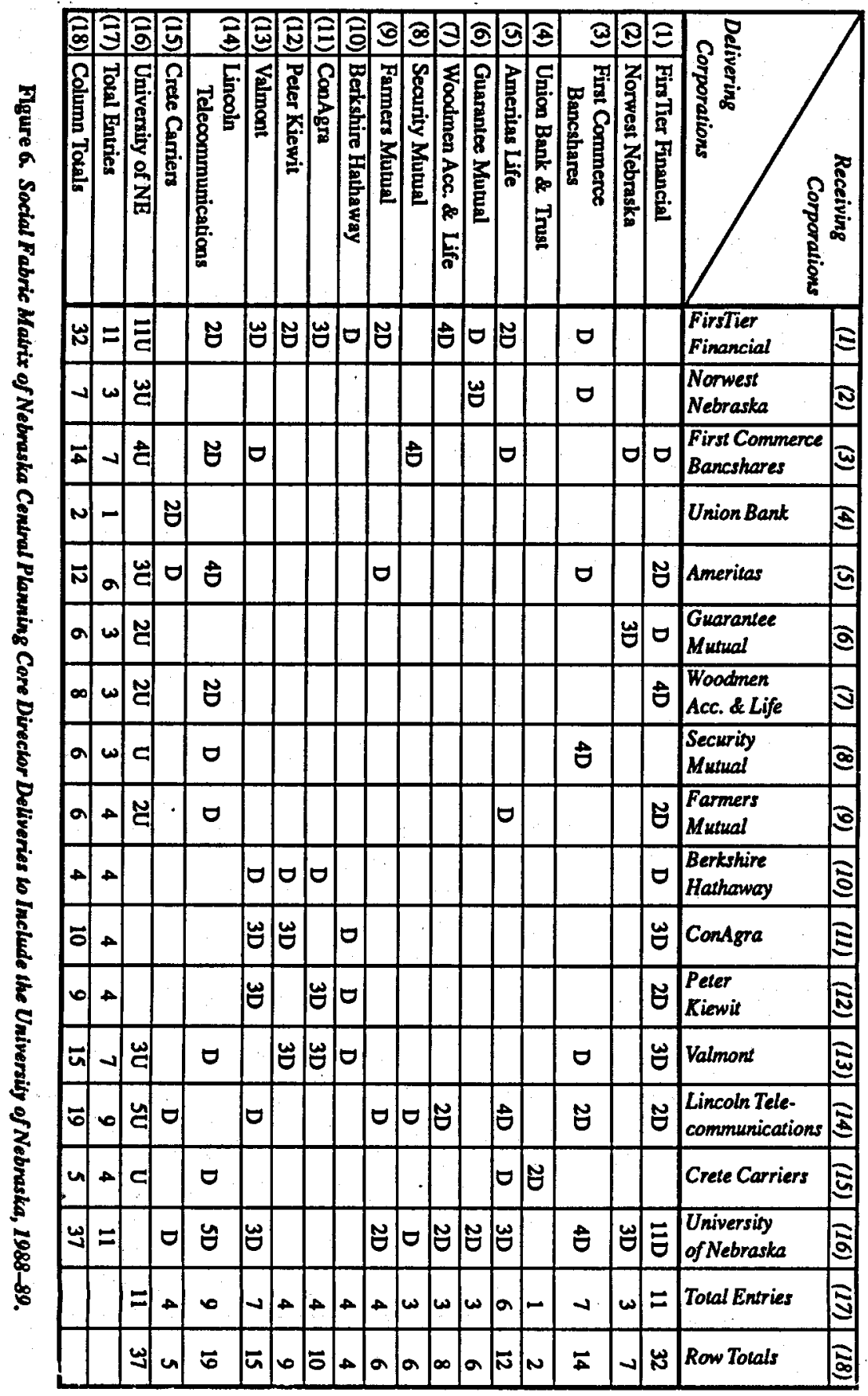


sure. "These boards are made up of well-to-do businessmen, with a penchant for popular notability; and the qualifications necessary to put in evidence by aspirants for executive office are such as will convince such a board of their serviceability" [Veblen 1957, p. 180]. There are many more candidates willing to serve such boards than positions available; thus, the aspirant's trial under fire provides a process to prove his aggressiveness and strength.

In point of fact, here as in political office-seeking, the most

active factor that goes to decide the selection of the eventual incumbents of office is a tenacious aggressive self-selection. With due, but by no means large, allowance for exceptions, the incumbents are chosen from among a self-selected body of candidates, each of whom has, in the common run of cases, been resolutely in pursuit of such an office for some appreciable time, and has spent much time and endeavor on fitting himself for its duties. Commonly it is only after the aspirant has achieved a settled reputation of eligibility and a predilection for the office that he will finally secure appointment [Veblen 1957, p. 179].

This was the university decision model that Veblen observed at the turn of the century for the major U.S. universities. Universities have, of course, changed considerably since that time in some ways consistent with, and, in other ways, in response to Veblen's suggestions and criticism. Veblen, however, was not modeling state universities. They were not the major universities early in this century.

\section{The NCPC/NU Social Fabric Matrix}

As we saw above, the decisionmaking institutions of the corporate business community have evolved to a new process since the time of Veblen. We should also expect that the relationship between modern state universities and the new business complex has also changed. Because the CPC is the dominant core of business decisions in the centrally private sector planning system, we might expect that a university's connection with the business community would be through the CPC. We will begin testing such a hypothesis by determining the relationships between the NCPC and the University of Nebraska (NU).

To outline the extent of such overlap, NU is added to the SFM of the NCPC found in Figure 4 above. The new SFM with NU included is found in Figure 6, and the digraph expressing the matrix of Figure 6 , as a directed graph, is found in Figure 7. Included in the NU system for 1988-1989 are the University of Nebraska-Lincoln (UN-L), the University of Nebraska-Omaha (UN-O), the University of Nebraska Medical Center, and the University of Nebraska Foundation. 


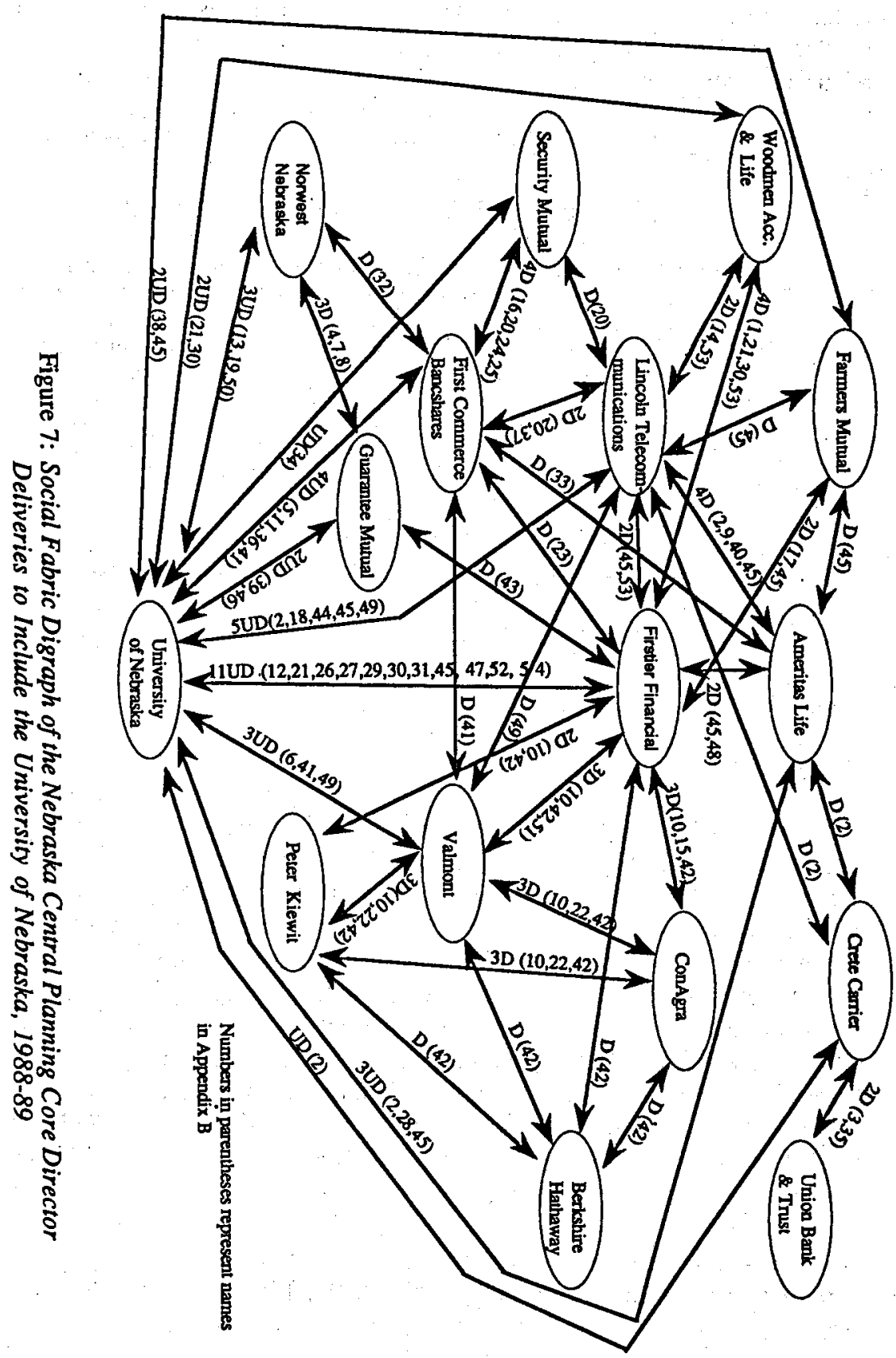


The delivery entries in Figure 6 are the same as in Figure 4 except for the NU system, added as row 16 and column 16. The entries in row. 16 are the deliveries made by NU to the NCPC corporations, and in column 16 the entries are the deliveries made from the NCPC corporations to NU. The deliveries from NU to the corporations are designated by $U$, which indicates that those persons are in an important decisionmaking position at the university. They all serve in two capacities-as a university official and as a corporate director. This becomes clear as we explain the row cells in Column 16 in which there are entries. They are as follows:

Matrix Cell

Explanation of Delivery

Row Cell $(1,16)$ FirsTier delivers 11 directors to NU positions. Those positions are: Chancellor of UN-L, Vice President of NU, Foundation Award Committee, Foundation Executive Committee, Foundation Administrative Committee, Foundation Development Committee, and eight of FirsTier's board directors serve on the Foundation Board of Directors (BOD).

Row Cell $(2,16)$ Norwest Nebraska delivers three directors to NU positions. Those positions are: Vice Chancellor of Un-L, Chancellor of Un-O, Vice President of NU, and two Foundation BODs.

Row Cell $(3,16)$ First Commerce Bancshares delivers four directors to NU positions. Those positions are: Athletic Director, Dean of the College of Business, UN-L, Foundation Nominating Committee, and a NU Regent.

Row Cell $(5,16)$ Ameritas Life delivers three directors to NU positions. Those positions are: Foundation Administrative Committee, Foundation Awand Committee, Foundation Executive Committee, and three Foundation BODs.

Row Cell $(6,16)$ Guarantee Mutual delivers two directors to NU positions. Those positions are: President of NU, Foundation Budget and Finance Committee, Foundation Executive Committee, and Foundation BOD.

Row Cell $(7,16)$ Woodman Accident \& Life delivers two directors to NU positions. Those positions are: Foundation Award Committee, Chancellor UN-L, Vice President of NU, and two Foundation BODs.

Row Cell $(8,16)$ Security Mutual delivers a director to a NU position. That position is Head Football Coach, UN-L.

Row Cell $(9,16)$ Farmers Mutual delivers two directors to NU positions. Those positions are: Foundation Budget and Finance Committee, Foundation Executive Committee, and Foundation BOD.

Row Cell $(13,16)$ Valmont delivers three directors to NU positions. Those positions are: Dean of the College of Business, UN-L Foundation Consultant, and Foundation Administrative Committee. 
Row Cell $(14,16)$ Lincoln Telecommunications delivers five directors to NU positions. Those positions are: Foundation Administrative Committee, Foundation Executive Committee, Foundation Consultant, Foundation Development Committee, and two Foundation BODs.

Row Cell $(15,16)$ Crete Carrier delivers a director to NU positions. Those positions are: Foundation Administrative Committee, Foundation Executive Committee, and Foundation BOD.

These entries are displayed in Figure 7. The digraph in Figure 7 indicates the number of UDs (a UD being a person who is both a $\mathrm{NU}$ official and a NCPC corporate director). Following the indication of the number of UDs are the numbers that correspond to the person's name in Appendix B. By adding NU to the NCPC matrix and digraph, the substantial degree to which the University is connected to the 15 core corporations, and the extent of their director deliveries, become clear. NU has more primary translocks than any other corporation in the matrix: there are 37 corporate officials involved in 11 primary translocks. In comparison, FirsTier, as the highest ranking corporation in primary translocks, has fewer the NU. FirsTier has 32 officials involved in $\mathbf{1 1}$ primary translocks. The highest number of primary locks between any two institutions occurs between FirsTier and NU. There are 11. Excluding the University, the greatest number of PCTs between two corporations is 4 . Of the 15 corporations that comprise the NCPC, 73 percent deliver at least 1 director to NU. The NCPC also provides almost 50 percent of the directors to the University of Nebraska Foundation Board of Directors, and holds 50 percent of the foundation committee chairships.

The overlap articulated here between the NCPC and NU should not be considered exhaustive. First, if documents that are not public could be accessed, there may be additional direct exchanges. Second, if additional corporations, beyond those in the core, were included in the matrix, additional connections between NU and the NCPC, through secondary and tertiary connections, would be articulated. Third, if different kinds of organizations, for example law firms, in addition to business corporations were included in the matrix, additional reachability between the CPC and NU would be defined. An example is the law firm of Cline, Williams, Wright, Johnson and Oldfather (Cline, Williams). Its clients include NU and FirsTier Bank. In 1988-1989, when Cline, Williams represented FirsTier and NU, Warren Johnson from their law firm was on the board of directors of FirsTier and also served on the University of Nebraska Foundation board of directors. Fourth, if different kinds of deliveries were included, additional over- 
laps would be specified. Numerous examples come to mind in this category. For example, Kiewit Construction was the contractor for the recently completed Durham lab science center at the University of Nebraska-Omaha campus, and Kiewit is currently building the health care facility at the University of Nebraska Medical Center. As another example, ConAgra has delivered money and expertise to the University of Nebraska-Lincoln for the establishment and purposes of the Agribusiness Program. The brochure for the Agribusiness Program states,

In 1981, ConAgra approached UN-L with the idea of an agribusiness program which would provide students with a sound background of both business and agriculture knowledge and skills. ConAgra and UN-L set goals for the program. ConAgra and the University Foundation committed five years of funding to give the program a sound start [Agribusiness Program].

This statement clarifies that it was not UN-L faculty or administrators who initiated the idea. Beyond initiating the idea, ConAgra helped set goals for the state university program. In addition, ConAgra, along with the NCPC directors who dominate the University Foundation, committed funding for the program. ${ }^{6}$

\section{Conchuding Observations}

This article extends the conceptual and applied analysis on the overlap of organizations by using the Social Fabric Matrix. From this endeavor, our concluding observations are as follows.

First, the application of the SFM extends the conceptual and applied knowledge base on overlaps in a number of ways. It provides a method for explicitly specifying the primary, secondary, and tertiary overlaps. Thus, it allows for a more complete organization of data for analysis. By using the SFM to ferret out these overlap sets, the large number of secondary and tertiary translocks, not previously discovered, are specified.

The SFM and its concomitant digraph allows for the description of the decision network that Veblen thought was necessary for meaningful theoretical work to be completed. The SFM digraph allows us to give more precision to the concept of process; in this case, the decision process among corporations. By specifying the decision network, the question with regard to the set of beliefs, myths, ideologies, and their legal expressions that guide the process pattern presents itself perforce. For policy purposes, the SFM must be expanded in the future to include these entities. 
All systems experience hierarchical arrangements that have to be articulated for the system to be understood. The SFM approach allows us to find the decision hierarchy by identifying both the central corporations and the reachability paths for information to be diffused from those corporations. Too many corporate overlap studies have ignored hierarchy and the central core corporations. By treating all corporations the same (of equal importance), the findings in the studies lose validity. For example, a number of studies have been completed on whether broken ties between corporations are reconstituted with the same firm. Most have ignored the hierarchy within the network by comparing total ties to reconstituted ties. However, Linda Stearns and Mark Mizuchi found that reconstitution is a function of the corporation's power in the network [Stearns and Mizuchi 1986, p. 536]. Thus, distinctions must be made with regard to a corporation's position in the hierarchy before other distinctions can be tested. "All social systems-hence, all organizations-exist in an institutional environment that defines and delimits social reality.... To neglect their presence and power is to ignore significant causal factors shaping organizational structures and practices: to overlook these variables is to misspecify our causal models" [Scott 1987, pp. 507-8].

The SFM approach does not prejudge where the center lies. In Nebraska, the CPC included corporations involved in banking, insurance, communications, food processing, equipment production, investment, transportation, and so forth. The SFM method determines the central core and the degree of reachability to the core, rather than forcing investigators to hypothesize the core.

Yngve Ramstad has stated that institutionalist knowledge gains plausibility and validation as it is validated in different contexts [Ramstad 1986, pp. 1072-73]. The findings in this article are a "real type." The real type is the Nebraska context and the findings are consistent with Munkirs's real type findings in the national context. This strengthens the theory [Ramstad 1986, p. 1072]. The next step, according to Ramstad, is to capture linkages and connections between the two contexts in order to constitute the system's unity and wholeness. "These specific linkages are what contribute to the system's uniqueness" [Ramstad 1986, p. 1072]. This article uncovers how to begin specifing that linkage. The linkage between the national CPC and NCPC, it appears, is accomplished by national and global corporations, such as IBP and ConAgra, which are linked to both the national and local systems.

With regard to the relationship between a modern state university and a state CPC, it is evident that the integration and overlap between 
the two is much more pervasive and complex than the simple relationship Veblen described as existing between governing boards and administrators early in this century. To correspond with Veblen's findings for the private university, we might have expected the NCPC to have overlapped extensively with the Board of Regents at NU. However, the NCPC is not integrated into NU's decisionmaking through NU's elected Board of Regents. Only one Regent held a position with a NCPC corporation. He held a position with a subsidary of a NCPC corporation. The integration of the NCPC and NU is accomplished by directors from NCPC corporations holding an extensive variety of decisionmaking positions at NU; they include Foundation committee members, the University President, Chancellors of UN-L and UN-O, Vice Chancellor, Athletic Director, Foundation Board of Directors, and so forth. They are in positions to influence the major decisions of the University. Corporate influence no longer obtrudes itself from outside into the university. It has become internalized within the university as academic administrators become active participants in the central planning core. Thus, the pecuniary logic now dominates from within the institution of higher learning. Whether this can be considered a general model, or just a special Nebraska case, will not be known until similar research is completed in other states with other state universities.

The findings in Nebraska also make us rethink where the center of the CPC may reside, especially at the regional level. Traditionally we have not thought of such extensive integration as found in Nebraska between the CPC and the university system. The Nebraska case may be, as stated earlier, unique. If it is not, what are the ramifications on a broader basis? To what extent does the corporate center reside in the university? We saw from the data above that the NU system has more primary overlaps with other corporations than FirsTier does. Thus, $\mathrm{NU}$ is also a potential translock for corporate planning. In addition, through NU the number of secondary and tertiary translocks among NCPC corporations are vastly increased.

The traditional statement about power is that power is dependent on a combination of wealth, violence, and knowledge. We would probably all find fault with the statement. For example, most of us would want technology and organization to be included. Whatever the final set of determinants of power we might agree upon, knowledge would be included. We also know that in a modern society, knowledge has become more important than the other determinants. This means that a knowledge center such as the university will become of greater interest to any 
organization seeking power. Thus, we could surmise that the university will become more integrated with the prominent core organizations of society. The questions of how the university overlaps with any societal institution it serves, and how a democracy can determine the answers to those questions require that serious attention be given to organizational overlap.

\section{Notes}

1. The data base was collected from public information sources. Those sources are listed below. The data base is for 1988 and 1989. Information from two years is included because the 1988-1989 data base best fits the 1988-1989 academic year at the University of Nebraska, and the final concern is with the relationship of the NCPC to the university. The sources are: Electronic Yellow Pages. 1989. Dunn and Bradstreet; Standard and Poor's Register of Corporations, Directors and Executives. 1989. New York: McGraw Hill: Vol 1; Annual Statements, Section D, 1988. Lincoln; State of Nebraska, Insurance Department; Domestic Corporation Occupation Tax Report. 1989. Lincoln: State of Nebraska, Office of the Secretary of State; McFadden American Bank Directory, Nebraska. 1989. Norcross, Ga.: McFadden Business Publications (Spring); Million Dollar Directory: America's Leading Public and Private Companies. 1989. Parsippany: Dunn and Bradstreet Corp; and Compact Disclosure Version 3.7US. 1989. Bethesda, Md.: Disclosure Incorporated (January).

2. The computer disk is available from the authors.

3. Among the smaller banks deleted from consideration for the CPC, there appears to be divided spheres of influence. There seem to be three distinct groups. In the first group, one member of the board of FirsTier Financial serves on the boards of Farmers State Bank and Trust-Aurora, First United Bank-Neligh, Farmers State Bank and Trust-Lexington, First National Bank-Wisner, and the Bank of Papillion. In a second group, one member of the Board of First National of Nebraska serves on the board of Farmers and Merchants-Bloomfield, Burt County Bank, Washington Bank, and Harlan County Bank. In the third group are members of the Acklie family. They serve on the Boards of the Bank of Norfolk, Packers Bank and Trust, and First National Bank of Lyons. Duane Acklie is also on the NCPC boards of Crete Carrier, Ameritas Life Ins., and Lincoln Telecommunications.

4. A qualitative survey needs to be conducted in the future to validate which weights are most appropriate.

5. Almost all of the NCPC members listed in Appendix B are non-Hispanic caucasian male Republicans.

6. The required and recommended courses in the Agribusiness Program do not include courses on (1) occupational health and safety, (2) environmental protection and regulation, (3) or anti-trust regulation. Anyone with even a newspaper acquaintance of the agribusiness industry knows those are three of the major areas of concern in the industry. 


\section{References}

Agribusiness Program. Agribusiness Advising Office. College of Agriculture or College of Business. University of Nebraska. Lincoln, Nebraska.

Bush, Paul Dale. 1983. "An Exploration of the Structural Characteristics of a Veblen-Ayres-Foster Defined Institutional Domain." Journal of Economic Issues 17 (March): 35-66.

1987. "The Theory of Institutional Change." Journal of Economic Issues 21 (September): 1075-1116.

Chamberlin, Edward H. 1962. The Theory of Monopolistic Competition. 8th edition. Cambridge: Harvard University Press.

Commons, John R. 1968. Legal Foundations of Capitalism. Madison: The University of Wisconsin Press.

Dewey, John and Arthur F. Bentley. 1949. Knowing and the Known. Boston: Beacon Press.

Evans, Bert M. 1980. "The Corporate Enterprise System: Competitive Ceremonial Waste and Environmental Destruction." Paper delivered at the annual meeting of the Western Social Science Association (April), Denver Colorado.

Fombrun, Charles J. 1986. "Structural Dynamics within and between Organizations." American Sociological Quarterly. 31 (September): 403-21.

Galbraith, John K. 1967. The New Industrial. Boston: Houghton Mifflin.

Gellen, Martin. 1984. "Institutional Economics and the Intellectual Origins of National Planning in the United States." Journal of Planning, Education and Research (December): 75-85.

Hayden, F. Gregory. 1982a. "Social Fabric Matrix: From Perspective to Analytical Tool." Journal of Economics Issues 16 (September): 637-61.

1982b. "Organizing Policy Research Through the Social Fabric Matrix: A Boolean Digraph Approach." Journal of Economic Issues 16 (December): 1013-26.

Leblebici, Huseyin and Gerald Salancik. 1982. "Stability in Interorganizational Exchange: Rule-making Processes of the Chicago Board of Trade". Administrative Science Quarterly. 27 (June): 227-42.

Munkirs, John R. 1985. The Transformation of American Capitalism: From Competitive Market Structures to Centralized Private Sector Planning. New York: M.E. Sharpe.

Ramstad, Yngve. 1986. "A Pragmatist's Quest for Holistic Knowledge: The Scientific Methodology of John R. Commons." Journal of Economic Issues 20 (December): 1067-1106.

Scott, W. Richard. 1987. "The Adolescence of Institutional Theory" Administrative Science Quarterly 32 (December): 493-511.

Stearns, Linda Brewster and Mark S. Mizruchi. 1986. "Broken-Tie Reconstitution and the Functions of Interorganizational Interlocks: A Reexamination." Administrative Science Quarterly 31 (December): 522-28.

Veblen, Thorstein. 1957. The Higher Learning in America: A Memorandum on the Conduct of Universities by Business Men. 3rd Edition. New York: Hill and Woing.

1898. "Why is Economics Not an Evolutionary Science?" Quarterly Journal of Economics 12 (July): 373-397. 


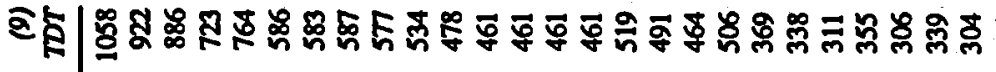

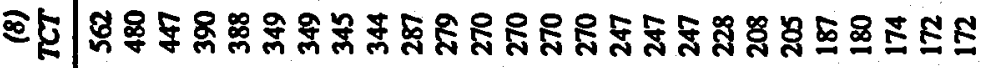

है

ह

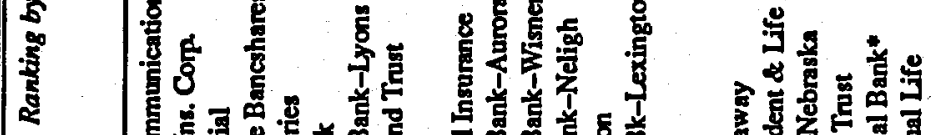

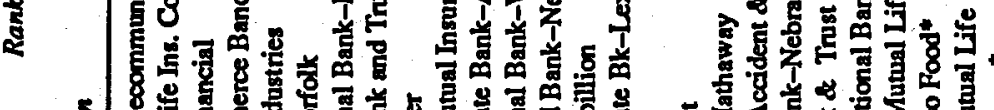

के

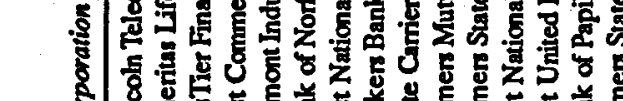

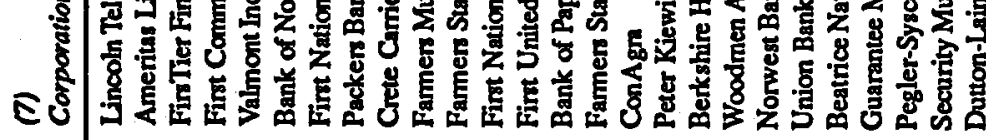

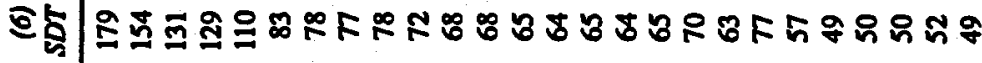

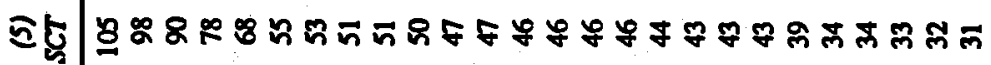
$\mathbf{5}$

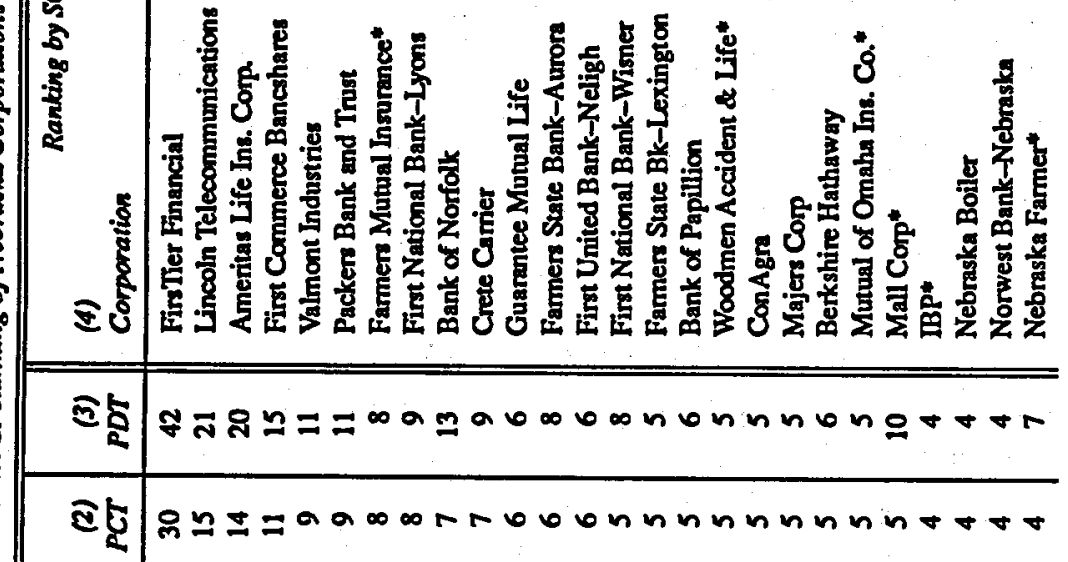

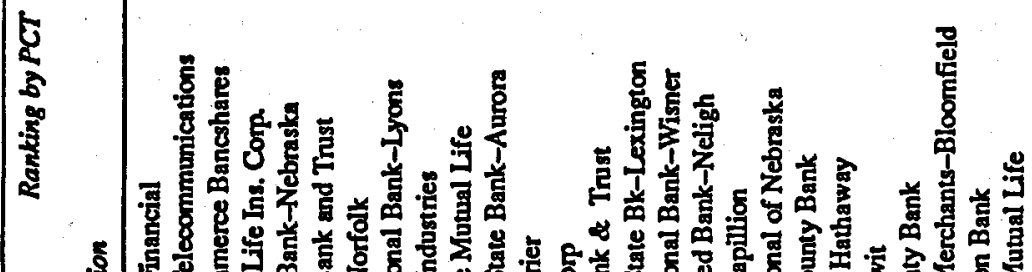

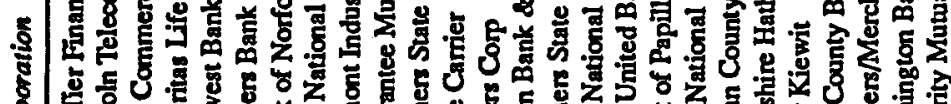

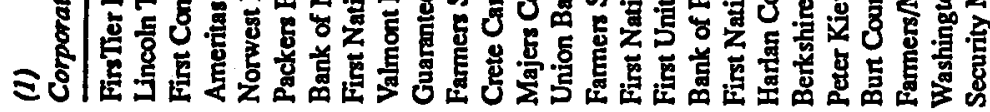



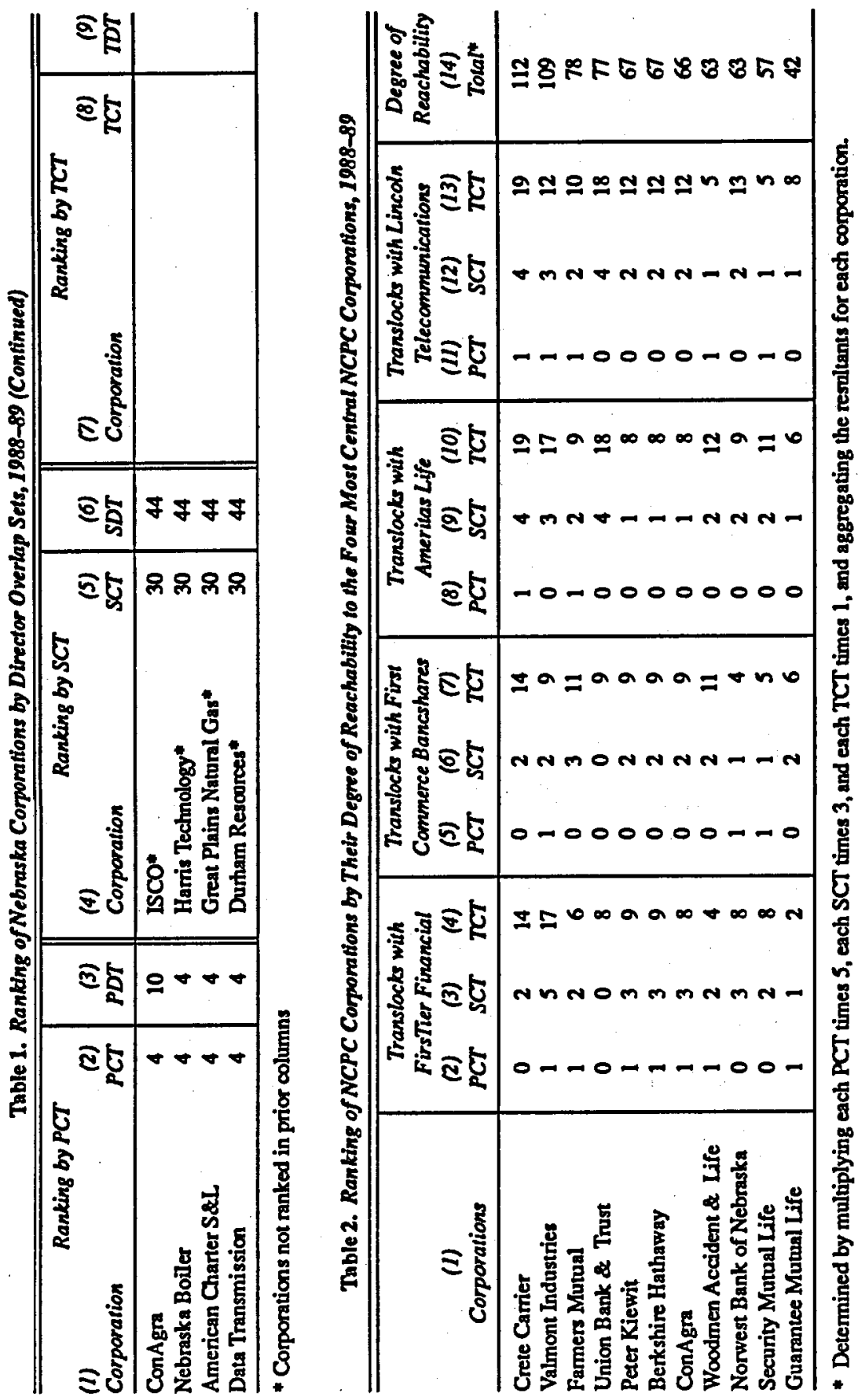


\section{Appendix A \\ Glossary of Acronyms and Symbols}

$\begin{array}{ll}\text { CPSP } & \text { Centralized Private Sector Planning } \\ \text { CPC } & \text { Central Planning Core } \\ \text { NCPC } & \text { Nebraska Central Planning Core } \\ \text { PCT } & \text { Primary Corporate Translock } \\ \text { PDT } & \text { Primary Director Translock } \\ \text { SCT } & \text { Secondary Corporate Translock } \\ \text { SDT } & \text { Secondary Director Translock } \\ \text { TCT } & \text { Tertiary Corporate Translock } \\ \text { TDT } & \text { Tertiary Director Translock } \\ \text { SFM } & \text { Social Fabric Matrix } \\ \text { SFD } & \text { Social Fabric Digraph } \\ \text { BOD } & \text { Board of Directors } \\ \text { D } & \text { Member of a Board of Directors } \\ \text { U } & \text { University Decision Maker } \\ \text { UD } & \text { University Decision Maker Who Is Also a Director for a Corporation } \\ \text { NU } & \text { University of Nebraska (Entire System) } \\ \text { UN-L } & \text { University of Nebraska-Lincoln } \\ \text { UN-O } & \text { University of Nebrasks-Omaha } \\ \text { B\&F } & \text { Budget and Finance Committee }\end{array}$

\section{Appendix B}

Persons Who Comprise the Nebraska Central Planning Core (NCPC) Translocks and Their Pasitions with NCPC Corporations and NU, 1988-89

1. Abel, George P.

2. Acklie, Duane

3. Acklie, Phyllis

4. Bekins, Fredrick M.

5. Calhoun, David

6. Cate, Sydney

7. Cochran, John $\mathrm{r}$.

8. Conley, Eugene A.

9. Cook, William W. Jr.
FirsTier Financial

Woodmen Acc. \& Life

University of Nebraska

University of Nebraska

University of Nebraska

Ameritas Life Ins.

Crete Carrier

Lincoln Telecommunications

Crete Carrier

Union Bank \& Trust

Guarantee Mutual Life

Norwest Nebraska

University of Nebraska

First Commerce Bancshares

University of Nebraska

Valmont

Guarantee Mutual Life

Norwest Nebraska

Norwest Nebraska

Guarantee Mutual Life

Ameritas Life

Lincoln Telecommunications
Director

Director

Foundation Adm Comm

Foundation Exec Comm

Foundation BOD

Director

Pres., Director

Director

VP, Director

Director

Director

Foundation Nom. Comm.

Foundation Nom Comm.

Director

Foundation Adm Comm

Director

Director

Pres., Director

Director

Pres., Director

Director

Director 
10. Daugherty, Robert B. ConAgra

FirsTier Financial

Peter Kiewit

Valmont

11. Devaney, Robert S.

13. Faith, Marshall

14. Faulkner, Edwin J.

15. Fletcher, Philip B.

16. Forke, Ted J.

17. Frazier, Larry A.

18. Geist, James

19. Goebel, John W.

20. Greer, J. Taylor

21. Haessler, John

22. Harper, Charles $\mathbf{M}$.

23. Heider, Charles F.

24. Henning, Thomas E

25. Holdt, Leland L.S.

26. Johnson, Warren

27. Klosterman, John

28. Maddux, W. John

29. Maenner, John $\mathbf{R}$.

30. Massengale, Martin
First Commerce Bancshares

University of Nebraska

University of Nebraska

Norwest Nebraska

Lincoln Telecommunications

Woodmen Acc. \& Life

ConAgra

FirsTier Financial

Security Mutual

First Commerce Bancshares

Farmers Mutual

Firstier Financial

University of Nebraska

Lincoln Telecommunications

Norwest Nebraska

University of Nebraska

Lincoln Telecommunications

First Commerce Bancshares

Security Mutual

University of Nebraska

University of Nebraska

Woodmen Acc \& Life

FirsTier Financial

ConAgra

Peter Kiewit

Valmont

FirsTier Financial

First Commerce Bancshares

First Commerce Bancshares

Security Mutual

First Commerce Bancshares

Security Mutual

University of Nebraska

Firstier Financial

University of Nebraska

University of Nebraska

FirsTier Financial

Ameritas Life

University of Nebraska

University of Nebraska

University of Nebraska

FirsTier Financial

Woodmen Acc. \& Life

University of Nebraska

University of Nebraska
Director

Director

Director

Chrm, Director

Director

Director

Foundation BOD

Director

Director

Director

President

Director

Director

Director

Pres., Director

Director

Foundation Adm Comm

CEO, Director, Pres.

Director

Vice Chancellor, UN-L

Director

Director

Director

Foundation Award Comm

Foundation BOD

CEO, Director

Director

Chrm, Director, CEO

Director

Director

Director

Director

Vice President

Director

Director

CEO, Director

Foundation Exec Comm

Director

Foundation BOD

Foundation Award Comm

Director

Director

Foundation BOD

Foundation Award Comm

Foundation Adm Comm

Director

Director

Chancellor, UN-L

Vice President 


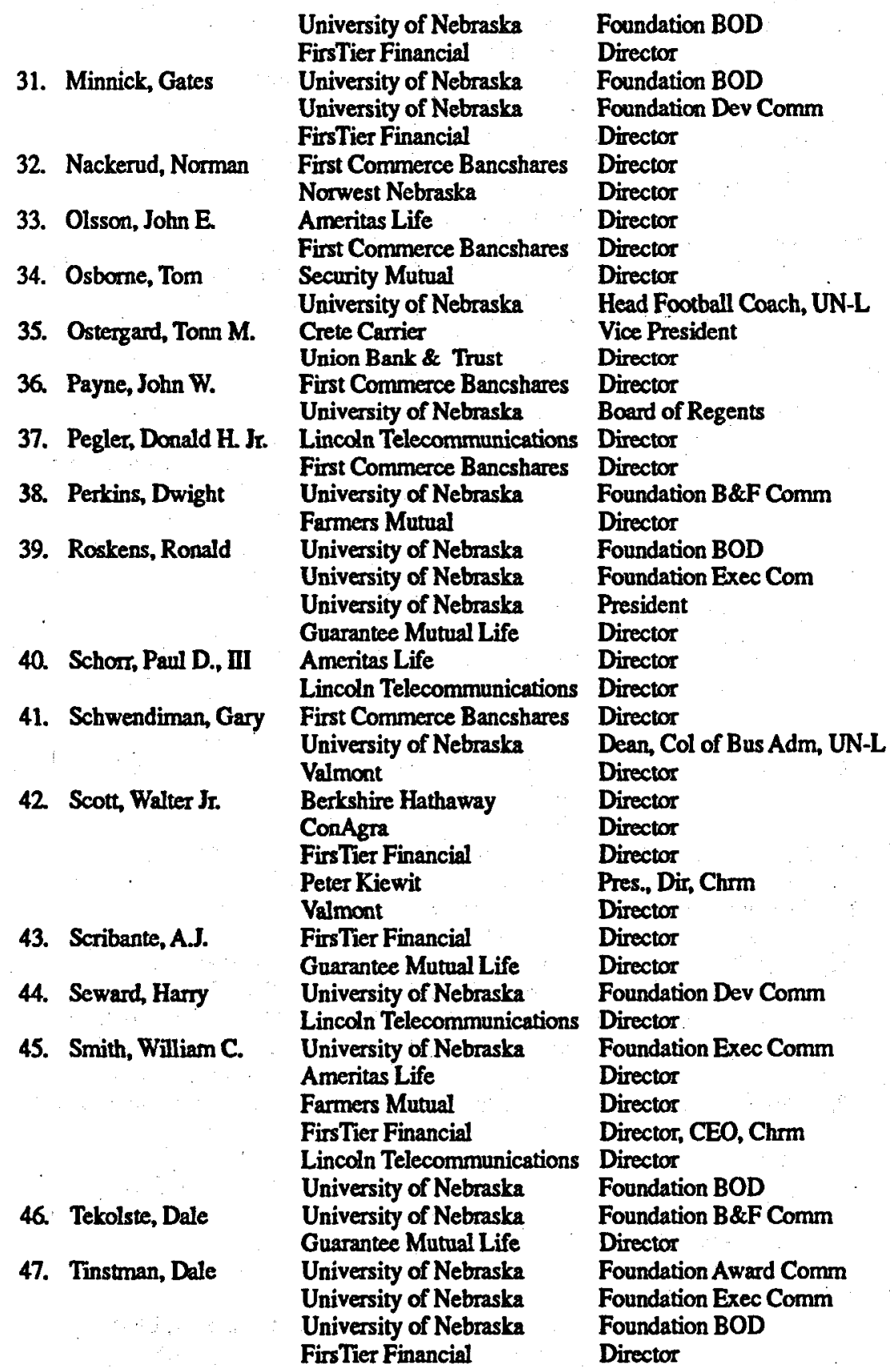


49. Vamer, Durward B.

50. Weber, Del
48. Tyner, Neal E.

Ameritas Life

FirsTier Financial

Lincoln Telecommunications

Valmont

University of Nebraska

Norwest Bank Nebraska

University of Nebraska

University of Nebraska

University of Nebraska

51. Welsh, William F., II

Firstier Financial

Valmont
52. Whitebead, Milton

University of Nebraska

FirsTier Financial

University of Nebraska

University of Nebraska

53. Woods, Thomas C. Jr. Firstier Financial

Lincoln Telecommunications

Woodmen Acc \& Life

54. Yanney, Michael
University of Nebraska

FirsTier Financial

University of Nebraska
Chrm, Pres., CEO, Director

Director

Director

Director

Foundation Consultant

Director

Foundation BOD

Chancellor, UN-O

Vice President

Director

CEO, Director

Foundation Exec Comm

Director

Foundation BOD

Foundation Nom Comm

Director

Chrm, Director

Director

Foundation BOD

Director

Foundation Dev Comm

* "This list of names corresponds to the translocks displayed in Figures 4, 5, 6, and 7. These members serve on additional (non-core) boands. This list, however, includes only their membership on the $\mathbf{1 5}$ core corporations and the University of Nebraska." 


\section{ERRATUM}

The following paragraphs were deleted from the printed version of F. Gregory Hayden and Kurt Stephenson, "Corporate Transorganization and Veblen's Thesis on Higher Education," Journal of Economic Issues 26, no.1 (March 1992): 53-85. The deleted paragraphs should follow the first paragraph under the heading "Relevant Corporate Transorganizational Literature" on page 56 :

Fombrun, in 1986, stated that we needed to recognize that "structure is a complex construct whose disaggregation in extant research has artificially compartmentalized complementary aspects of organization." He believed that theories of structure had artificially segregated various streams of organizational research. He stated that structure should be understood to be a configuration of infrastructure, sociostructure, and superstructure. "Thus within organizations, structure is an edifice resting on the intrastructural foundation of a technological solution to the production problem, framed by a sociostructure of interactions, around which crystallizes a set of superstructural norms and values" [Fombrun 1986, 406; emphasis added]. Fombrun seemed to be unaware of the works of Bert M. Evans and John R. Munkirs that had already established corporate transorganizational approaches.

For years Professor Evans taught at the University of Nebraska that the economy of the United States is a corporate enterprise economy and not a free enterprise economy. It is an economy which is planned at the center, by what Fombrun referred to as the sociostructure corporations. According to Evans, that sociostructure of large banks and insurance companies overlaps with the production infrastructure to guide the producers at the national and the local levels.

One of Evans' professors at Harvard, Edward H. Chamberlain, developed the theory of monopolistic competition about which he stated, in 1933, that most industries had evolved to a point that they were dominated by a few firms. These firms, Chamberlain stated, without overt collusion or organizational overlap, recognized their interdependence; and thus, in their pricing, production and distribution policies, each corporation took into consideration the reaction of others to its own decisions. Chamberlain indicated 
that this system of mutual dependence recognized led to problems such as monopoly pricing, unemployment, and economic waste [Chamberlain 1962]. Evans followed the lead of another of his professors, John $\mathrm{K}$ Galbraith, who had found the corporate sector in the U.S. to be planned [Galbraith 1967]. In his own work, Evans observed that the system had evolved beyond one of mutual dependence recognized to one of mutual advantage recognized arrangements among corporations. Corporations were no longer just recognizing other corporations. They had evolved to a point of arranging for pervasive overlapping decision making and planning for their mutual advantage. Evans referred to this as a corporate enterprise system, as opposed to the free enterprise system of an earlier era. The corporate enterprise system "does not compete in the old-fashioned economic sense. Rather the economic struggles center around strategies for control. ..." [Evans 1980, 2]. "It isn't competition-it is the mutual adoption and standardization of methods of avoiding the effects of competition" [1980,6].

Evans divided his explanation into two historical stages. "Stage one became a matter of business stabilization through mutual accommodation within the industrial family" [1980, 10]. These industrial families "shared markets and adopted product and pricing patterns ..." $[1980,7]$. Stage two of the corporate enterprise system developed as overlapping arrangements across industries acquired a larger share of the growing national product.

The multi-national, dominant core, shared monopoly groups. . . looked at each other and saw that in some cases one industrial or product line group or another received a bigger piece of the bigger pie than themselves. It became apparent to these industrial or business groups that it wasn't enough to protect themselves within the group. Mutual advantage recognized arrangements worked within the group; but each saw the need for a strategy to secure a larger piece of the growing pie [1980,8].

According to Evans a central core, whose regular practices had not solidified (although he believed that it was dominated by New York banks and insurance companies) gave guidance to the system. Central core decisions emanate from the collective overlap of numerous cores. "The dominant cores of the various multinational industrial or business groups collectively have set the pattern and mostly the rest of us try to survive" [1980,9].

All citations are to references listed in Hayden and Stephenson [1992]. 